\title{
MAINTENANCE OF DIVERSITY WITHIN PLANT COMMUNITIES: SOIL PATHOGENS AS AGENTS OF NEGATIVE FEEDBACK
}

\author{
Katherine E. Mills and James D. Bever ${ }^{1}$ \\ Department of Botany, Duke University, Durham, North Carolina 27708-0338 USA
}

\begin{abstract}
The effect of soil pathogens on plant communities was investigated using four old-field perennial plant species and five isolates of a pathogenic oomycete in the genus Pythium. These Pythium strains were isolated from the roots of two of the plant species, Danthonia spicata and Panicum sphaerocarpon, used in a previous experiment on the consequences of changes in the soil community on plant growth. In this previous experiment, Danthonia and Panicum changed the soil community in a manner that reduced their growth relative to that of a third plant species, Anthoxanthum odoratum. In the current experiments, we found that inoculation with Pythium reduced overall plant mass and root: shoot ratios, but Danthonia and Panicum were more susceptible to the presence of Pythium than the other two plant species, Anthoxanthum and Plantago lanceolata. In addition, Pythium accumulates at different rates on different plant species, with a greater than tenfold higher population observed in association with Panicum compared to Anthoxanthum. The results of these experiments suggest that the accumulation of species-specific soil pathogens could account for the previous observation of negative feedback on plant growth through changes in the soil community. As negative feedback may act to maintain plant species diversity within a community, these results suggest that soil pathogens may themselves contribute to the maintenance of plant species diversity.
\end{abstract}

Key words: Anthoxanthum; community dynamics; Danthonia; diversity; feedback; host specificity; old field; Panicum; Plantago; Pythium; pathogen; soil community.

\section{INTRODUCTION}

It has traditionally been assumed that the maintenance of plant community diversity results from the partitioning of abiotic resources (reviewed by Grace and Tilman 1990, Tilman and Pacala 1993). Models of competition reveal that competing species will coexist when intraspecific competition exceeds interspecific competition, a situation that has generally been presumed to result from abiotic niche differentiation. However, the generality of this view has recently been challenged (e.g., Silvertown and Law 1987, Aarssen 1989) and a potential role of pathogens in mediating species interactions, and particularly plant-plant coexistence, has been suggested (Holt and Pickering 1985, Burdon 1987, Alexander 1990). The importance of pathogens is supported by their ubiquitous occurrence and major impacts on agricultural plant populations. Moreover, recent work in natural communities has found substantial impacts of pathogens on plant demography (Weste 1974, Augspurger 1984, 1988, 1990, Burdon 1987, Alexander et al. 1996) and even suggests a role of pathogens in the course of dune succession (Van der Putten et al. 1993). Nevertheless, the overall role of pathogens in the maintenance of

Manuscript received 31 January 1997; revised 16 July 1997; accepted 20 July 1997.

${ }^{1}$ Author and present address for correspondence: Department of Ecology and Evolution, The University of Chicago, 1101 East 57th Street, Chicago, Illinois 60637-1573. diversity in natural plant communities is not known. This is particularly true for soil pathogens, a group known to be important in agricultural systems (Bruehl 1987, Agrios 1988) but which are unusually difficult to study because of the confounding effects of, and complexity of interactions with, other components of the soil community (e.g., Larkin et al. 1993, Newsham et al. 1995, De Rooij-van der Goes 1995, Bever et al. 1997).

We have found evidence that the soil community, as a whole, can contribute to the maintenance of diversity within plant communities. Using a phenomenological experimental approach, we have found strong negative feedbacks on plant growth through changes in the composition of the soil community (Bever 1994, Bever et al. 1997). Negative feedback occurs when the presence of a plant changes the soil community in a manner that decreases the growth of that particular plant species relative to other species. Models of this process have shown that negative feedback can maintain diversity of a plant community provided that the sign of an interaction coefficient is negative (Bever et al. 1997). This interaction coefficient can be estimated in experimental studies where plants of a particular species are transplanted into soil communities that have previously been "cultured" by plants of the same ("home") or a different ("away") species; thus, the coefficient can be estimated using a "home vs. away" contrast (Bever 1994). In previous studies we found evidence for the existence of negative feedback between Anthoxanthum 
odoratum and Danthonia spicata and between A. odoratum and Panicum sphaerocarpon in an old-field community in Durham, North Carolina (Bever 1994). Specifically, Bever (1994) found that growth of D. spicata and $P$. sphaerocarpon was significantly reduced with soil communities that had been previously "cultured" by plants of the same species, while A. odoratum did well in these soils but exhibited reduced growth with soil communities that had previously supported plants of its own species. In independent experiments, we also found evidence of negative feedback between the pairs Anthoxanthum and Plantago, and Panicum and Plantago (Bever et al. 1997).

The agents of negative feedbacks in these studies have not been identified, but initial observations indicated that accumulation of species-specific soil pathogens may be responsible. D. spicata and $P$. sphaerocarpon both had low root: shoot ratios, likely the result of observed root necrosis (Bever 1994). Several species of soil pathogens, including species of the genus Pythium, were subsequently isolated from their roots. It is possible that the observed accumulation of Pythium on these two plant species causes more severe effects on $D$. spicata and $P$. sphaerocarpon than on other plant species, suggesting that soil pathogens contribute to the observed negative feedback and thereby play an important role in the maintenance of diversity within this plant community.

In this study, we used these isolates of Pythium spp. to test whether the accumulation of species-specific soil pathogens may contribute to the negative feedback observed between certain plant species. Although Pythium spp. are known to have substantial impacts on plant survival and growth (reviewed in Hendrix and Campbell 1973, Abad et al. 1994, Larkin et al. 1995), the impact of Pythium on unmanaged plant communities has rarely been investigated (but see Augspurger 1990). To investigate the role of soil pathogens in affecting plant community diversity, we tested the effect of $P y t h-$ ium spp. on the growth of the plant species in which negative feedback through the soil community had previously been observed (Bever 1994). We then discuss these results in light of the observations of whole-soil community feedback to provide insight into the potential impacts of soil pathogens on plant community diversity.

\section{Methods}

In order to investigate the role of Pythium in feedback processes within the soil community, we focused on two questions: (1) Do different species of plants exhibit differential responses to the presence of Pythium and (2) Do Pythium spp. accumulate differentially under these plant species? These objectives were evaluated in two experiments. A full factorial experiment in which four plant species were grown in six treatments consisting of five isolates of Pythium and a sterile control allowed us to test differential responses of each plant species to the presence of Pythium and to specific Pythium isolates. Host-specific differences in rates of accumulation of Pythium were assessed using a series of serial dilutions of soil from A. odoratum and $P$. sphaerocarpon.

\section{Study system}

The plants, pathogens, and soil used for this experiment were obtained from a well-studied old field in Durham, North Carolina. The plant community in this field is diverse and lacks any distinctly dominant species (Fowler and Antonovics 1981). Four common, short-lived perennial plant species were used in this study-three grasses, Anthoxanthum odoratum L., Danthonia spicata (L.) Beauv., and Panicum sphaerocarpon Ell., and a herbaceous species, Plantago lanceolata L. Hereafter, all plant species will be referred to by generic name only. Negative feedback on plant growth through changes in the soil community had previously been observed between four of the six pairs of plant species: Anthoxanthum and Danthonia, Anthoxanthum and Panicum, Anthoxanthum and Plantago, and Panicum and Plantago (Bever 1994, Bever et al. 1997). However, in three separate test experiments, no feedback was observed between Danthonia and Panicum (Bever 1994).

The isolates of Pythium (a genus popularly regarded as fungal but accurately classified as an oomycete in the Kingdom Chromista) used in this experiment were cultured from roots of Danthonia and Panicum remaining from a previous experiment that demonstrated negative feedback between these species and Anthoxanthum (Bever 1994). We were not able to obtain isolates of Pythium from Anthoxanthum roots. Five isolates identified as four different Pythium species were cultured in a manner described below-Pythium aristosporum, $P$. arrhenomanes, and $P$. macrosporum from Danthonia and $P$. arrhenomanes and $P$. volutum from Panicum (G. Abad, personal communication). The species of Pythium isolates used in this study infect a wide variety of hosts (Abad et al. 1994, Deep and Lipps 1996, Magarey 1996). In addition, $P$. aristosporum, $P$. arrhenomanes, and $P$. volutum have all been classified as "highly aggressive" species due to their severe impacts on growth and survival of grasses (Abad et al. 1994).

\section{Experiment 1: Plant response to Pythium}

Isolation of Pythium.-Isolates of Pythium were obtained from root tissues of Danthonia and Panicum using techniques similar to those described by Martin (1992). Samples of roots from these grasses were rinsed thoroughly with water, surface sterilized with $50 \%$ ethyl alcohol, and then dried with sterile paper towels before being placed onto selective media (PARP — pentachloronitrobenzene ampicillin rifampicin pimaricin medium) (Jeffers and Martin 1986). Following incubation at room temperature for $48 \mathrm{~h}$, isolates were trans- 
ferred to fresh plates of PARP, and isolate purity was confirmed by growing on corn-meal agar (CMA) (Difco Laboratories, Detroit, Michigan). Species identity of the isolates was determined using sterile grass blade cultures with assistance from M. Cubeta and G. Abad, and stock cultures were stored as agar plugs in test tubes containing sterile deionized water at room temperature.

Preparation of Pythium inoculum.-Pythium inoculum containing active mycelia and oospores that could survive in and infest the soil of treatment plants was prepared by growing the five Pythium isolates in sterile grass blade cultures (Martin 1992). For each of the Pythium isolates, two plugs (each $0.5 \mathrm{~cm}^{3}$ ) of CMA with mycelium were placed in separate sterile tissue culture dishes (Falcon $3025,150 \times 25 \mathrm{~mm}$ style). Sterile deionized water was added to the dishes to a level where the layer of water just covered the agar plugs, and 50 pieces (each $1.0-1.5 \mathrm{~cm}$ long) of autoclaved tall fescue grass leaves were placed into each dish. Five replicate dishes containing the grass blade cultures of each isolate were incubated at room temperature under continuous light for $4 \mathrm{~d}$ (Abad et al. 1994). Infection of the grass blades by the Pythium mycelia was monitored under the dissecting scope, and the experiment was planted $4 \mathrm{~d}$ after the grass blade cultures were started, at which time most blades of grass had been infected by the mycelia.

Planting and harvesting processes.-Seedlings of Anthoxanthum, Panicum, and Plantago were started from seeds of greenhouse-grown plants that were previously collected from the field. Danthonia seeds were collected from plants in our study field. All seeds were planted in sterile seedling mix and were allowed to grow until small seedlings of each species were available. In April 1996, between seven and ten replicates of each of the six treatments were planted with each plant species. All plants for this experiment were grown in $385-\mathrm{mL}$ pots filled with sterile background soil. To prepare the background soil, field soil was first crumbled until it passed through a $1-\mathrm{cm}$ mesh. Equal amounts of the sieved field soil and sand were then thoroughly mixed and autoclaved for $1.5 \mathrm{~h}$.

Each Pythium treatment was inoculated with one of the isolates of Pythium by placing four colonized grass blades from the sterile grass blade culture beneath the top $70 \mathrm{~mL}$ of soil in each pot. Control treatments were planted in the same manner with sterile uninoculated grass blades being used in place of the Pythium inoculum. Two seedlings of one of the plant species were planted in each pot. The entire experiment was then arranged into two randomized blocks within a greenhouse $\left(10.0^{\circ}-32.2^{\circ} \mathrm{C}\right)$ and pots were spaced sufficiently to prevent cross-contamination by water splash during the course of the experiment. All pots were kept well watered during the first few days of the study to allow initial establishment of the seedlings and Pythium. After the $1 \mathrm{st} \mathrm{wk}$, the pots were watered as needed.
The first block of the experiment was harvested 5 wk after planting, while the second block grew for 7 wk. During the harvesting process, whole plants were removed from the soil and washed. Roots and leaves were cut apart to be dried and weighed separately. Small root samples were also taken from select pots of the first block and from all pots in the second block to confirm the presence of Pythium using the same process described previously.

Data analysis.-Masses of the leaves and roots from both plants in each pot were summed, and the effect of the Pythium treatments and plant species on total plant mass and root: shoot ratios was analyzed with an analysis of variance using the general linear models procedure of SAS (SAS 1986). The treatment and interaction sums of squares were decomposed into orthogonal tests (1) of the control treatment against the average effects of the Pythium isolates and (2) among the Pythium isolates. This technique allows us to separate effects caused by the presence of Pythium in general from specific effects of individual isolates. We were particularly concerned with whether differences in susceptibility could explain the previous observation of negative feedback through the soil community between these plant species (Bever 1994). In the earlier studies, the feedbacks were tested using pairwise home vs. away contrasts (Bever 1994, Bever et al. 1997). Feedbacks between the plant species could result from the accumulation of Pythium in association with one of these plant species, followed by that plant species being more susceptible to the presence of Pythium than other plant species in the community. Therefore, in this experiment, we were specifically interested in evaluating pairwise differences between the four plant species in susceptibility to the Pythium isolates. These differences were tested as the single degree of freedom interaction between two plant species and the presence of Pythium. Because the pairwise contrasts were not orthogonal, their significance was adjusted by the Dunn-Sidák method to control for multiple tests (Sokal and Rohlf 1981). In testing for interspecific differences in response to specific isolates of Pythium, we were also interested in the a priori hypothesis of local adaptation of the Pythium isolates from Panicum and Danthonia to their hosts. This hypothesis was tested by contrasting the average response of Danthonia to isolates cultured from Danthonia, and Panicum to isolates cultured from Panicum, against the average response of these two grass species to isolates from the other species.

\section{Experiment 2: Pythium infection of various plant species}

Differential growth rates of Pythium on two of the plant species, Anthoxanthum and Panicum, were tested in this experiment. Field soil was collected from beneath the two plant species, diced, and homogenized to create soil communities that were initially similar 
(as in Bever 1994). This fresh soil mixture was distributed into replicate pots into which were planted six soil-microbe-free tillers (as in Bever 1994) of either Anthoxanthum or Panicum. The plants were watered as needed but were not fertilized while growing in a Duke University Phytotron controlled environment chamber under $12 \mathrm{~h}$ light and at $25^{\circ} \mathrm{C}$ during the day and $10^{\circ} \mathrm{C}$ at night. After $7 \mathrm{mo}$, three cores ( $1 \mathrm{~cm}$ diameter) were taken from each of the nine replicate culture pots, and the soil from the cores of each pot was homogenized to obtain one pooled sample per culture pot. For each homogenized sample, two replicates of three serial dilutions were evenly spread onto selective media (PARP). Pythium colonies were counted after $48 \mathrm{~h}$. Colony-forming units per gram soil were estimated based on plate counts. The average inoculum density for each pot was analyzed in an ANOVA using the general linear models procedure of SAS (SAS 1986).

\section{RESUlts}

Experiment 1: plant response to Pythium

The presence of Pythium reduced plant mass and root: shoot ratios. Plants grown with four of the five Pythium isolates had plant masses (Fig. 1a) and root: shoot ratios (Fig. 1b) that were significantly lower than the control treatment. Further, plant species varied in their susceptibility to the presence of Pythium in general (as tested by the Plant spp. $\times$ Pythium interaction, Table 1). Specifically, Danthonia and Panicum were more susceptible to Pythium than Anthoxanthum and Plantago (pairwise contrasts in Table 1, Fig. 2). This was demonstrated by the fact that masses (Fig. 2a) and root: shoot ratios (Fig. 2b) of Danthonia and Panicum infected by Pythium were less than those species under control conditions, while the masses of Anthoxanthum and Plantago did not seem affected by Pythium infection.

Although the plants differed in their response to the presence of Pythium in general, they did not differ in their response to specific isolates of Pythium (as tested by the Plant spp. $\times$ Pythium spp. interaction, Table 1 ). Of particular interest, we did not find a difference in susceptiblilty between Danthonia and Panicum to their own or each other's isolates. Thus, there is no evidence of differential adaptation of the isolates from Danthonia and Panicum on their respective hosts (Danthonia vs. Panicum, Table 1).

\section{Experiment 2: Pythium infection of various plant species}

Results of colony formation assays for serial dilutions of Anthoxanthum and Panicum soil confirmed that Pythium populations reached higher densities in the soil of Panicum than Anthoxanthum $\left(F_{1,16}=41.11, P<\right.$ $0.0001)$. The mean number of colony-forming units of Pythium from Anthoxanthum pots was 161.1, while the mean colony-forming units from the Panicum pots was 2411.1.
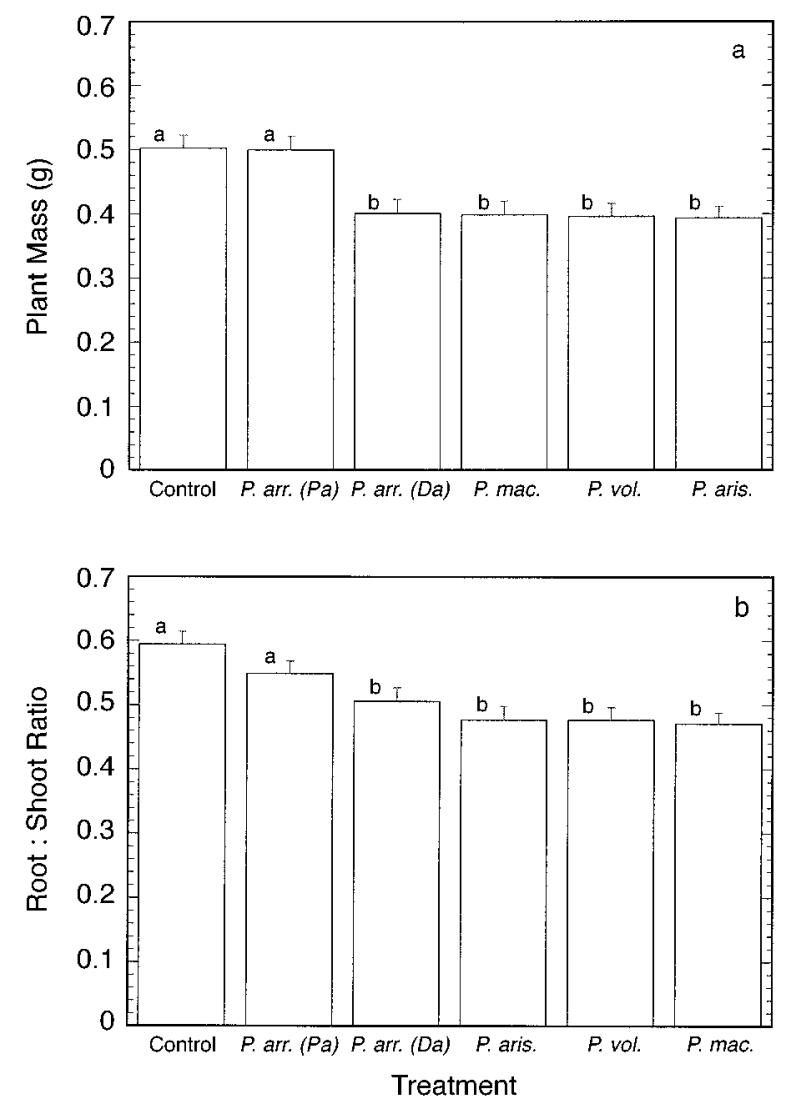

FIG. 1. Average effect of Pythium isolates on plant growth. The average response of the four plant species to the Pythium isolates and the control are presented for plant mass (a) and root: shoot ratios (b). The least square means and 1 SE are presented. Different letters indicate significant differences in means among the treatments as tested using Tukey's test for multiple comparisons. For these graphs, isolates of Pythium are abbreviated as follows: "P. arr." for $P$. arrhenomanes, "P. aris." for $P$. aristosporum, "P. mac." for $P$. macrosporum, and "P. vol." for P. volutum. "P. arr. $(P a)$ ", indicates that this isolate of $P$. arrhenomanes obtained from roots of Panicum, and "P. arr. $(D a)$ " indicates that this isolate was obtained from roots of Danthonia.

\section{DISCUSSION}

This study indicates that soil pathogens may play a role in maintaining plant community diversity by preferentially infecting and subsequently inhibiting the growth of certain species. Some plant species were more susceptible to harmful effects of Pythium infection than others, with Danthonia and Panicum being more negatively impacted than Anthoxanthum and Plantago. These host-specific effects may explain the previous observations of negative feedback through the soil community between these plant species (Bever 1994, Bever et al. 1997). For example, the negative feedback observed between Panicum and Anthoxanthum (Bever 1994, Bever et al. 1997) may result from the increase in density of Pythium in response to culturing with Panicum as evidenced by root necrosis, 
TABLE 1. Analyses of covariance of plant masses and root: shoot ratios for the comparison of Pythium treatments.

\begin{tabular}{|c|c|c|c|c|c|}
\hline \multirow[b]{2}{*}{ Source of variation $\dagger$} & \multirow[b]{2}{*}{ df } & \multicolumn{2}{|c|}{ Plant mass } & \multicolumn{2}{|c|}{ Root: shoot ratios } \\
\hline & & ss & $P$ & SS & $P$ \\
\hline $\begin{array}{l}\text { Block } \\
\text { Plant spp. }\end{array}$ & $\begin{array}{l}1 \\
3\end{array}$ & $\begin{array}{l}6.002 \\
4.257\end{array}$ & $\begin{array}{l}0.0001 \\
0.0001\end{array}$ & $\begin{array}{l}0.032 \\
7.918\end{array}$ & $\begin{array}{c}\mathrm{NS} \\
0.0001\end{array}$ \\
\hline Treatment & 5 & 0.390 & 0.0001 & 0.396 & 0.0001 \\
\hline $\begin{array}{l}\text { Control vs. Pythium } \\
\text { Among Pythium spp. }\end{array}$ & $\begin{array}{l}1 \\
4\end{array}$ & $\begin{array}{l}0.147 \\
0.237\end{array}$ & $\begin{array}{l}0.0010 \\
0.0016\end{array}$ & $\begin{array}{l}0.254 \\
0.136\end{array}$ & $\begin{array}{l}0.0001 \\
0.0321\end{array}$ \\
\hline Plant spp. $\times$ Treatment & 15 & 0.325 & 0.0618 & 0.391 & 0.0134 \\
\hline $\begin{array}{l}\text { Plant spp. } \times \text { Pythium } \\
\text { An }-D a \times \text { Pythium }\end{array}$ & $\begin{array}{l}3 \\
1\end{array}$ & $\begin{array}{l}0.230 \\
0.019\end{array}$ & $\begin{array}{l}0.0007 \\
\text { NS }\end{array}$ & $\begin{array}{l}0.260 \\
0.101\end{array}$ & $\begin{array}{l}0.0002 \\
0.0052\end{array}$ \\
\hline$A n-P a \times P y$ thium & 1 & 0.145 & 0.0020 & 0.155 & 0.0012 \\
\hline$A n-P l \times P y$ thium & 1 & 0.004 & NS & 0.000 & NS \\
\hline Da-Pa $\times$ Pythium & 1 & 0.060 & NS & 0.006 & NS \\
\hline Da-Pl $\times$ Pythium & 1 & 0.039 & NS & 0.102 & 0.0100 \\
\hline$P a-P l \times$ Pythium & 1 & 0.195 & 0.0004 & 0.157 & 0.0010 \\
\hline Plant spp. $\times$ Pythium spp. & 12 & 0.103 & NS & 0.141 & NS \\
\hline Danthonia vs. Panicum & 1 & 0.003 & NS & 0.000 & NS \\
\hline Error & 167 & 2.169 & & 2.101 & \\
\hline
\end{tabular}

Note: The Plant spp. $\times$ Treatment interaction tests for differences in responses of the four plant species to the control treatment or the five Pythium treatments. This overall interaction term was decomposed into two orthogonal interaction components: the Plant spp. $\times$ Pythium interaction and the Plant spp. $\times$ Pythium spp. interaction. The Plant spp. $\times$ Pythium interaction specifically tests for differences among the four plant species in their average response to the five Pythium isolates compared to the sterile control. This interaction component was itself decomposed into six pairwise tests for differential response to the presence of Pythium. The Plant spp. $\times$ Pythium spp. interaction component tests for differences in hostspecific effects among the five Pythium isolates.

$\dagger$ Plant species abbreviations are as follows: "An" = Anthoxanthum, "Da" = Danthonia, "Pa" = Panicum, "Pl" = Plantago.

reduced root: shoot ratios, and isolation of Pythium spp. in the whole-soil feedback experiment (Bever 1994), and the empirical comparison of Pythium colony-forming units isolated from Anthoxanthum and Panicum in this experiment. This increased density of Pythium may then decrease the growth of Panicum in its local Pythium-enriched soil relative to the growth of Anthoxanthum in the same soil. The first experiment also provides evidence that Pythium may be an agent of negative feedback observed previously between $A n$ thoxanthum and Danthonia, Anthoxanthum and Panicum, and Panicum and Plantago (Bever 1994, Bever et al. 1997). Our results further suggest that these strains of Pythium do not contribute to the negative feedback on plant growth previously observed between Anthoxanthum and Plantago (Bever et al. 1997). The host-specific effects of Pythium found in our study combined with observations of greater competitive ability of Danthonia (Kelley and Clay 1987) and Panicum (Westover 1995) may work together to maintain these plant species in the community. In addition, other environmental factors, such as aphid-transmitted viruses in Anthoxanthum (Kelley 1994) and the aerially transmitted fungal pathogen Fusarium monofiliforme in Plantago (Alexander 1984) may limit plant population densities in this community. As negative feedback leads to the maintenance of diversity within a community and this study identifies soil pathogens as potentially important agents of this feedback, we suggest that soil pathogens may contribute to the maintenance of diversity within a plant community.
The differential response of the four plant species to Pythium was not isolate specific. This, in part, may reflect a generalized resistance or tolerance of Anthoxanthum and Plantago to these root pathogens. However, even Danthonia and Panicum, the more susceptible plant species, did not differ in their responses to individual isolates of Pythium. In fact, there was no evidence that the pathogens isolated from Danthonia exerted a greater effect on that species than the pathogens isolated from Panicum or vice versa (as tested by the Danthonia vs. Panicum contrast, Table 1). This lack of difference among the isolates is consistent with the absence of a differential response of Danthonia and Panicum to each other's soil communities in three separate measurement attempts (Bever 1994).

While the consistency of results between this experiment and previous observations of feedback through the whole-soil community provides strong evidence that Pythium contribute to the observed feedback, we cannot rule out important roles for other components of the soil community. Other potential pathogens (e.g., a Fusarium species was also isolated from Panicum; J. D. Bever and S. P. Bentivenga, personal observations) may be important. Moreover, the communities of rhizosphere bacteria (Westover 1995) and the arbuscular mycorrhizal fungi (Bever et al. 1996) also exhibited striking host-specific differentiation on these plant species, and the differentiation of these communities may contribute to the whole-soil feedback on the plant growth. It is also possible that mycorrhizal fungi and rhizosphere bacteria, which were excluded 

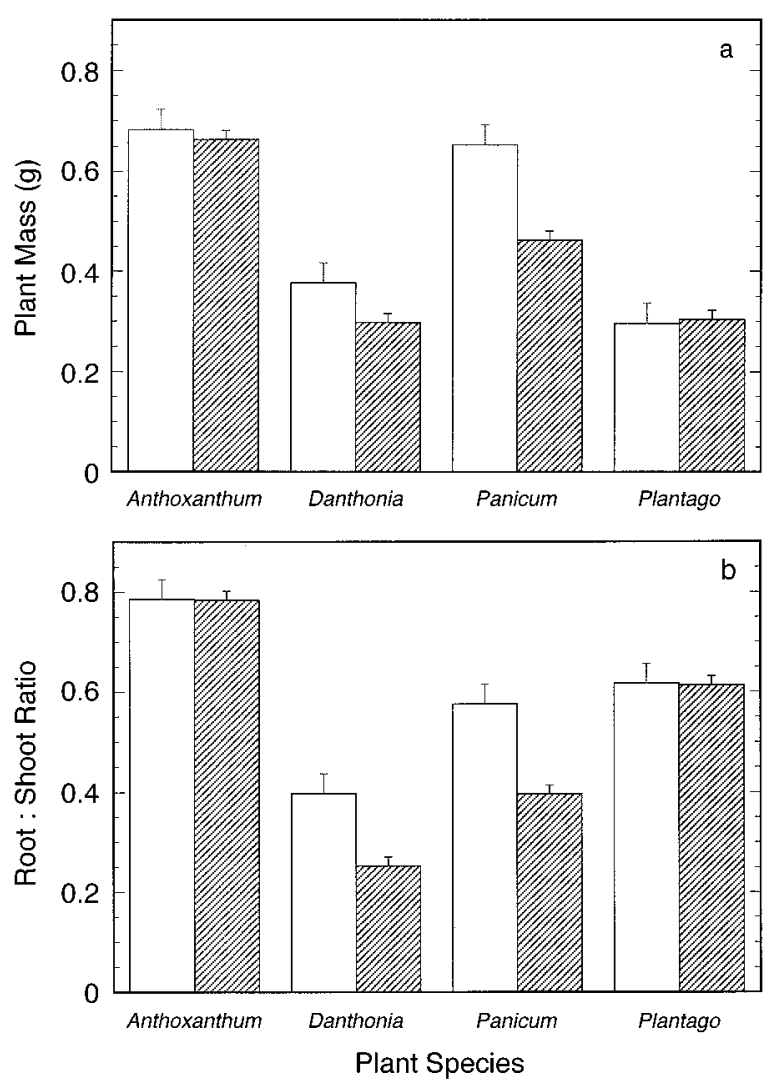

FIG. 2. The response of four plant species to the presence of Pythium. The average responses to the five Pythium isolates [hatched bars], and to the sterile control [open bars], are presented for each of the four plant species. The least square mean plant mass (a) and root: shoot ratios (b) and 1 SE are presented.

from the present study, could modify the effects of the soil pathogens (Newsham et al. 1995), though this possibility is not supported by the consistency of the results of the present study and the whole-soil tests of feedback.

This experiment provides evidence that Pythium can be detrimental to the growth of certain species within a diverse plant community. Previous studies have largely focused on disease and mortality effects of Pythium on agronomically important plants (reviewed in Hendrix and Campbell 1973, Larkin et al. 1995, Pankhurst et al. 1995, Deep and Lipps 1996, Magarey 1996, Rizvi and Yang 1996). Only five plants died during the period of this study, and those deaths cannot be conclusively related to the presence of Pythium. In fact, as observed previously by Larkin and others (1995), most of the plants inoculated with Pythium in this experiment remained asymptomatic throughout the course of the study. Although no disease was obvious, the pathogen decreased plant productivity and inhibited root system development in two of the four plant species. Newsham and others (1994) also suggested that asymptomatic levels of root pathogen infection can alter plant fecun- dity in the field. Furthermore, four of the five isolates of Pythium used in our experiment were identified as species of Pythium (G. Abad, personal communication) that have been classified as "highly aggressive" (Abad et al. 1994) due to their disease-causing potential on other plant species. However, in this seminatural grassland the two isolates of the "aggressive" Pythium arrhenomanes differed in their aggressiveness, with one isolate not producing significant reductions in growth (Fig. 1). The other isolates did not differ in their effects on plant size.

This study indicates that while Pythium reduces the growth and root development of plants overall, certain plant species proved more susceptible to Pythium infection, and this differential susceptibility to the pathogens studied suggests that soil pathogens may be agents of negative feedback. These results further support observations of negative feedback between these same plant species. Previous work indicates that this feedback is mediated through changes in their whole-soil communities and, in combination with the present study, indicates that the host-specific effects of these pathogens may not be substantially modified by other components of the soil community. Together these studies suggest that soil pathogens may strongly influence plant community composition and contribute to the maintenance of plant diversity.

ACKNOWLEDGMENTS

We thank K. Westover, P. Thrall, A. Pringle, J. Antonovics, J. Mihail, H. Alexander, J. Holah, T. Miller, and two anonymous reviewers for helpful comments on this manuscript. We are particularly grateful to G. Abad, M. Cubeta, and S. Bentivenga for advice and assistance in the isolation, culturing, and identification of the Pythium isolates. This work was made possible by USDA grants 92-37101-7461 and 9437101-0354, and by NSF grant DEB-9615941.

\section{Literature Cited}

Aarssen, L. W. 1989. Competitive ability and species coexistence: a "plant's-eye view." Oikos 56:386-401.

Abad, Z. G., H. D. Shew, and L. T. Lucas. 1994. Characterization and pathogenicity of Pythium species isolated from turfgrass with symptoms of root and crown rot in North Carolina. Phytopathology 84:913-921.

Agrios, G. N. 1988. Plant pathology. Third edition. Academic Press, San Diego, California, USA.

Alexander, H. M. 1984. Spatial patterns of disease induced by Fusarium monofiliforme var. subglutinans in a population of Plantago lanceolata. Oecologia 62:141-143.

2. 1990. Dynamics of plant-pathogen interactions in natural plant communities. Pages 3-14 in J. J. Burdon and S. R. Leather, editors. Pests, pathogens, and plant communities. Blackwell Scientific, Oxford, UK.

Alexander, H. M., P. H. Thrall, J. Antonovics, A. M. Jarosz, and P. V. Oudemans. 1996. Population dynamics and genetics of plant disease: a case study of anther-smut disease. Ecology 77:990-996.

Augspurger, C. K. 1984. Seedling survival among tropical tree species: interactions of dispersal distance, light-gaps, and pathogens. Ecology 65:1705-1712.

- 1988. Impact of pathogens on natural plant populations. Pages 413-433 in A. J. Davy, M. J. Hutchings, and A. R. Watkinson, editors. Plant population ecology. Blackwell Scientific, Oxford, UK. 
1990. Spatial patterns of damping-off disease during seedling recruitment in tropical forests. Pages 3-14 in J. J. Burdon and S. R. Leather, editors. Pests, pathogens, and plant communities. Blackwell Scientific, Oxford, UK.

Bever, J. D. 1994. Feedback between plants and their soil communities in an old field community. Ecology 75:19651977.

Bever, J. D., J. B. Morton, J. Antonovics, and P. Schultz. 1996. Host-dependent sporulation and species diversity of arbuscular mycorrhizal fungi in a mown grassland. Journal of Ecology 84:71-82.

Bever, J. D., K. M. Westover, and J. Antonovics. 1997. Incorporating the soil community into plant population dynamics: the utility of the feedback approach. Journal of Ecology 85:561-573.

Bruehl, G. W. 1987. Soilborne plant pathogens. Macmillan, New York, New York, USA.

Burdon, J. J. 1987. Diseases and plant population biology. Cambridge University Press, Cambridge, Massachusetts, USA.

Deep, I. W., and P. E. Lipps. 1996. Recovery of Pythium arrhenomanes and its virulence to corn. Crop Protection 15:85-90.

De Rooij-van der Goes, P. C. E. M. 1995. The role of plantparasitic nematodes and soil-borne fungi in the decline of Ammophila arenaria (L.) Link. New Phytologist 129:661669.

Fowler, N. L., and J. Antonovics. 1981. Competition and coexistence in a North Carolina grassland. I. Patterns in undisturbed vegetation. Journal of Ecology 69:825-841.

Grace, J. B., and D. Tilman. 1990. Perspectives on plant competition. Academic Press, San Diego, California, USA.

Hendrix, F. F., Jr., and W. A. Campbell. 1973. Pythiums as plant pathogens. Annual Review of Phytopathology 11:7798.

Holt, R. D., and J. Pickering. 1985. Infectious disease and species coexistence: a model of Lotka-Volterra form. American Naturalist 126:196-211.

Jeffers, S. N., and S. B. Martin. 1986. Comparison of two media selective for Pythophthora and Pythium spp. Plant Disease 70:1038-1043.

Kelley, S. E. 1994. Viral pathogens and the advantage of sex in the perennial grass Anthoxanthum odoratum. Philosophical Transactions of the Royal Society of London, Series B, Biological Sciences 346:295-302.

Kelley, S. E., and K. Clay. 1987. Interspecific competitive interactions and the maintenance of genetic variation within two perennial grasses. Evolution 41:92-103.

Larkin, R. P., J. T. English, and J. D. Mihail. 1995. Identification, distribution and comparative pathogenicity of
Pythium spp. associated with alfalfa seedlings. Soil Biology and Biochemistry 27:357-364.

Larkin, R. P., D. L. Hopkins, and F. N. Martin. 1993. Effect of successive watermelon plantings on Fusarium oxysporum and other microorganisms in soils suppressive and conducive to Fusarium wilt of watermelon. Phytopathology 83:1097-1105.

Magarey, R. C. 1996. Microbiological aspects of sugarcane yield decline. Australian Journal of Agricultural Research 47:307-322.

Martin, F. N. 1992. Pythium. Pages 39-49 in L. L. Singleton, J. D. Mihail, and C. M. Rush, editors. Soilborne phytopathogenic fungi. American Phytopathological Society Press, St. Paul, Minnesota, USA.

Newsham, K. K., A. H. Fitter, and A. R. Watkinson. 1994. Root pathogenic and arbuscular mycorrhizal fungi determine fecundity of asymptomatic plants in the field. Journal of Ecology 82:805-814.

Newsham, K. K., A. H. Fitter, and A. R. Watkinson. 1995. Arbuscular mycorrhiza protect an annual grass from root pathogenic fungi in the field. Journal of Ecology 83:9911000.

Pankhurst, C. E., H. J. McDonald, and B. G. Hawke. 1995. Influence of tillage and crop rotation on the epidemiology of Pythium infections of wheat in a red-brown earth of South Australia. Soil Biology and Biochemistry 27:10651073.

Rizvi, S. S. A., and X. B. Yang. 1996. Fungi associated with soybean seedling disease in Iowa. Plant Disease 80:57-60.

SAS. 1986. SAS system for linear models. SAS Institute, Cary, North Carolina, USA.

Silvertown, J., and R. Law. 1987. Do plants need niches? Some recent developments in plant community ecology. Trends in Ecology and Evolution 2:24-26.

Sokal, R. R., and F. J. Rohlf. 1981. Biometry. W. H. Freeman, San Francisco, California, USA.

Tilman, D., and S. Pacala. 1993. The maintenance of species richness in plant communities. Pages 13-25 in R. E. Ricklefs and D. Schluter, editors. Species diversity in ecological communities: historical and geographical perspective. University of Chicago Press, Chicago, Illinois, USA.

Van der Putten, W. H., C. Van Dijk, and B. A. M. Peters. 1993. Plant-specific soil-borne diseases contribute to succession in foredune vegetation. Nature 362:53-56.

Weste, G. 1974. Phytophthora cinnamoni-the cause of severe disease in certain native communities in Victoria. Australian Journal of Botany 22:1-8.

Westover, K. M. 1995. The role of rhizosphere soil microorganisms in plant competition and coexistence. Dissertation. Washington State University, Pullman, Washington, USA. 